\author{
해양부산물 아미노산액비 및 유용미생물시용이 \\ 인삼의 품질에 미치는 영향 \\ 안 승 원 \\ 공주대학교 원예학과 \\ (2012년 7월 10일 접수; 2012년8월 27일 수정; 2012년8월 28일 채택)
}

\title{
Effect of Korean Effective Microorganisms and Seafood Amino Acid Fertilizer on the Root Quality of Panax ginseng
}

\author{
Seoung-Won Ann ${ }^{*}$ \\ Department of Horticulture, Kongju University, Chungnam 340-702, Korea \\ (Manuscript received 10 July, 2012; revised 27 August, 2012; accepted 28 August, 2012)
}

\begin{abstract}
Contents of ginsenosides 7 subordinations of two-year ginseng (fresh ginseng) is $1.27 \%$ and three-year ginseng is $2.09 \%$, so the three-year ginseng root increased $64.9 \%$ compared to the two-year root. Compared with the comparison group, ginsenosides component content of KEM+SAF-applied group increased $24 \%$ in case of the two-year root and $20 \%$ in case of the three-year root. In vitamin C content, two-year root showed 59.4\% higher and three-year root showed 37.7\% higher in $\mathrm{KEM}+\mathrm{SAF}$ applied group compared with the comparison group. In case of vitamin E, the two-year root indicated $5.6 \%$ higher and three-year root indicated $1.5 \%$ higher in KEM+SAF applied group compared with the comparison group, but there is no significant difference. In phytosterol three components (campesterol, stigmasterol, sitosterol), two-year root showed 25.3, 3.6, 14.1\% higher for each, and three-year root showed 23.6, 6.8, 12.9\% higher in KEM+SAF applied group and $14.4 \%$ was higher on average. In DPPH, two-year root indicated $34.4 \%$ higher and three-year root indicated $42.4 \%$ higher in KEM+SAF applied group compared to the comparison group. To sum up the results, KEM+SAF applied group showed (1) $22 \%$ ginsenosides components content, (248.6\% vitamin C content, (3) 3.6\% vitamin E content, (4) $14.4 \%$ phytosterol content, (5)38.4\% DPPH higher averagely compared to the comparison group.
\end{abstract}

Key Words : Panax ginseng, Korean effective microorganisms, Seafood amino acid fertilizer, Ginsenoside, Vitamin, Phytosterol

\section{1. 서 론}

현재 농업인들이 직면하고 있는 작물의 영양관리 및 병해충관리 기술을 통한 안전하고 기능성이 풍부 한 우수농산물 생산으로 고소득을 올릴 수 있는 다양 한 연구가 시행하고 있다(안과 김, 2010). 이들 다양한

${ }^{*}$ Corresponding author : Seoung-Won Ann, Department of Horticulture, Kongju University, Chungnam 340-702, Korea Phone: +82-41-330-1224

E-mail: annsw@kongju.ac.kr
기술 중에 유기물의 분해자역할을 하는 유용미생물의 발효 및 활용기술의 확립과 작물의 유기영양을 공급 하는 농수산 부산물 재활용 기술이 요구되고 있다(김 등, 1997; 안과 김, 2010). 유용미생물의 농업적 활용 으로 농업 부산물의 부숙 촉진효과 및 생물학적 방제 제로 살균 및 살충력을 이용한 생물 농약, 미생물이 분 비하는 각종 영양 및 생리활성물질 등으로 이용하고 있다(김 등, 1999; 나 등, 1997; 比嘉, 1991). 해양부산 물의 발효퇴비는 다양한 미네랄과 아미노산 등을 함 
유하고 있어 작물재배에 종합영양제로 활용이 가능하 다(比嘉, 1991). 이러한 식물에 대한 직접적인 아미노 산의 작용 외에도 토양미생물의 영양원으로 작용하여 미생물의 증식을 활발하게 하여 식물의 뿌리활력과 토양 부식의 기본이 된다(Cho 등, 1993; Park 등, 1993; 堀井, 2000).

인삼의 기능성물질에 대한 연구는 1960 년대에 인 삼 사포닌 배당체인 ginsenoside Rx 13종이 존재함을 분리하여 그 화학적 구조의 동정을 시작으로 최근까지 고려인삼에서 분리된 ginsenoside는 30 여종에 이르고 있으며 이들은 주로 triterpenoid 그룹의 dammarane계 사포닌으로서 인삼 속 식물에만 존재하는 특유의 사 포닌들이다(김 등, 1999; 김, 2008; 도와 이, 1993; 박, 1991; 양, 1991; 최, 1991). 그리고 수삼 생중량당 ginsenoside(7종) 함량도 2 5년차 까지 급격히 증가하여 묘삼의 2 배에 달한다. 그러나 6 년차 이후의 ginsenoside 함량은 변화가 적다(도와 이, 1993; 양, 1991; 최, 1991). 본 연구는 고려인삼(Panax Ginseng C.A. Meyer) 을 대상으로 유용미생물(Korean effective microorganisms: $\mathrm{KEM}$ )과 수산 부산물을 재활용한 생선아미노산액비 (Seafood amino acid fertilizer: SAF) 시용이 인삼의 기능성물질 함량변화에 미치는 영향에 대하여 2년생 과 3 년생 수삼을 대상으로 수행하였다.

\section{2. 재료 및 방법}

인삼의 재배포장은 금산군 금산읍 $\left(36^{\circ} 05^{\prime} 44^{\prime \prime}\right.$ $\mathrm{N}, 127^{\circ} 30^{\prime} 36^{\prime \prime} \mathrm{E}$ )에 위치한 인삼농가에서 2006년 과 2007년에 각각 1 년생 묘삼을 4월 20일에 정식하였 다. 두둑의 뒤쪽에 큰 지주를 세우고 연목을 연결하는 후주연결식 구조로, 이랑규격은 두둑폭 $90 \mathrm{~cm}$, 고랑폭 $90 \mathrm{~cm}$, 두둑높이 $35 \mathrm{~cm}$, 길이 $25 \mathrm{~m}$ 로 설치하였다. $\mathrm{KEM}+$ $\mathrm{SAF}$ 처리구는 정식 후 1,2 년근 인삼포장에서 4월 20 일부터 10 일 간격으로 각각 500 배액으로 희석하여 엽 면살포하였고, 2008년 10월 20일에 수확하였다. 수확 즉시 동결건조 $\left(-60^{\circ} \mathrm{C}, 96\right.$ 시간 $)$ 하여 성분의 파괴 없이 건물화 하여 분석하였다. Ginsenoside 분석은 현재까 지 분리, 동정된 30 여종의 ginsenoside 중에서 생리활 성 연구를 통해서 밝혀진 단일 ginsenoside 7종속을 분 석하였다. 그리고 vitamin C, vitamin E, phytosterol, 활
성산소 소거능 DPPH (1,1-Diphenyl-2 -picrylhydrazyl) 를 분석하였다.

\subsection{Ginsenoside 분석}

현재까지 분리, 동정된 30 여종의 ginsenoside 중에서 생리활성 연구를 통해서 밝혀진 단일 7종속 ginsenoside $\mathrm{Rb}, \mathrm{Rb}_{2}, \mathrm{Rc}, \mathrm{Rd}, \mathrm{Re}, \mathrm{Rf}, \mathrm{Rg}_{1}$ 에 대하여 분석하였다. 시료는 80 100메쉬로 분쇄하고, $1 \mathrm{~g}$ 을 취하여 250 $\mathrm{m} \ell$ flask 에 $70 \%$ 메탄올 $70 \mathrm{~m} \ell$ 과 혼합하여 $80^{\circ} \mathrm{C}$ water bath에서 60 분간 환류 추출(2회)하였다. 그리고 $60^{\circ} \mathrm{C}$ 감압 농축 후 물 $25 \mathrm{ml}$ 에 용해하고 시료 $5 \mathrm{ml}$ 을 Sep-Pak C18 plus에 흡착 시킨 후 물 $20 \mathrm{ml} 1$ 차 세척, $30 \%$ 메탄올 $15 \mathrm{ml}$ 2차 세척하여 메탄올 $5 \mathrm{ml}$ 로 용출 후 $0.45 \mu \mathrm{m}$ syringe filter로 여과하여 UPLC(모델명: ACQUITY UPLC)로 분석하였다(Table 1).

Table 1. Ginsenoside analysis conditions

\begin{tabular}{cccc}
\hline Solvent & $\begin{array}{c}\text { Flow velocity } \\
\text { Time }(\mathrm{m} / \mathrm{min})\end{array}$ & $\mathrm{H}_{2} \mathrm{O}(\%)$ & $\mathrm{ACN}(\%)$ \\
\hline \hline 0.0 & 0.6 & 85.0 & 15.0 \\
0.5 & 0.6 & 85.0 & 15.0 \\
14.5 & 0.6 & 70.0 & 30.0 \\
15.5 & 0.6 & 68.0 & 32.0 \\
16.5 & 0.6 & 60.0 & 40.0 \\
17.0 & 0.6 & 45.0 & 55.0 \\
19.0 & 0.6 & 45.0 & 55.0 \\
21.0 & 0.6 & 10.0 & 90.0 \\
22.0 & 0.6 & 85.0 & 15.0 \\
\hline Column & ACQUITY UPLC BEH C18 1.7 $\mu \mathrm{m}(2.1 \times 50 \mathrm{~mm})$ \\
\hline Column temp & \multicolumn{4}{c}{$40^{\circ} \mathrm{C}$} \\
\hline Wavelength & $203 \mathrm{~nm}$ \\
\hline Injection volume & $1 \mu \mathrm{m}$ \\
\hline
\end{tabular}

\subsection{Vitamin $\mathrm{C}$ 와 $\mathrm{E}$ 분석}

$\mathrm{O}$ Vitamin $\mathrm{C}$ 성분 분석 (ascorbic acid)

동결 건조된 시료 $5 \mathrm{~g}$ 을 $5 \mathrm{~m} \ell$ 의 $10 \%$ meta인산에 10 분간 침윤시킨 후, 막자사발과 유봉을 이용하여 $5 \%$ 메타인산을 용액에 넣어가며 분쇄하고, 최종부피가 $50 \mathrm{~m} \ell$ 가 되도록 정용하였다. 상기용액을 $5,000 \mathrm{rpm}$ 에 서 15 분간 원심분리하고, 상징액을 $0.4 \mu \mathrm{m}$ 의 nyon membrane filter로 여과한 후 HPLC로 분석하였다. $\mathrm{HPLC}$ 컬럼은 $4.6 \times 250 \mathrm{~mm}(5 \mu \mathrm{m})$ 의 luna $\mathrm{C}_{18} 100 \mathrm{~A}$ 를 사용하고, 유속은 $1.0 \mathrm{~m} \ell / \mathrm{min}$, 검출기는 UV $254 \mathrm{~nm}$ 의 
조건에서 분석하였다.

$\bigcirc$ Vitamin $\mathrm{E}$ 성분 분석 ( $\mathrm{a}-, \beta$-, $\gamma-$, and $\delta$-tocopherol)

시료 $0.5 \mathrm{~g}$ 을 ascorbic acid $0.1 \mathrm{~g}$ 과 EtOH $5 \mathrm{~m} \ell$ 이 포 함된 시험관에 넣고, $80^{\circ} \mathrm{C}$ shaking water bath에서 10 분간 방치 $(\mathrm{rpm}=90)$ 후 즉시 $44 \% \mathrm{KOH} 150 \mu \ell$ 를 넣 고, 다시 $80^{\circ} \mathrm{C}$ shaking water bath에서 18 분간 비누화 반응을 진행시켰다. 18 분경과 후 즉시 꺼내서 미리 준 비한 얼음에 넣어 냉각한 후 증류수 $5 \mathrm{ml}$, hexane $5 \mathrm{ml}$ 넣은 후 교반하였다. 원심분리 $\left(5^{\circ} \mathrm{C}, 1,000 \mathrm{rpm}, 1\right.$ 분 $)$ 후 상층액을 파스테르 pipet으로 취하여 $100 \mathrm{ml}$ 분액여 두에 옮기고, 하층액이 남아있는 원심분리 tube에 앞에 서와 동일한 조건으로 hexane $5 \mathrm{~m} \ell$ 를 넣고 vortex, centrifuge, 상층액을 파스테르 pipet으로 취해 $100 \mathrm{ml}$ 분액여두에 옮기는 과정을 2 번 더 수행하고 합쳐진 분 액여두에 증류수를 $5 \mathrm{ml}$ 넣어 흔든 후 물층을 버리는 과정을 3 회 반복하였다. 깔대기에 준비된 여과지를 깔 고 $\mathrm{Na}_{2} \mathrm{SO}_{4}$ 약 $4 \mathrm{~g}$ 을 넣은 후, hexane층을 $\mathrm{Na}_{2} \mathrm{SO}_{4}$ 에 통과시키면서 시험관에 받아 $\mathrm{N}_{2}$ gas 를 불어 hexane을 제거하고 Isooctane (HPLC) $1 \mathrm{~m} \ell$ 를 넣어 완전히 녹인 후 일회용 주사기를 이용하여 syringe filtration(nylon, 지름 $13 \mathrm{~mm}, 2 \mu \mathrm{m})$ 을 하여 sample vial(amber)에 담고, $\mathrm{N}_{2}$ 불어넣으며 밀봉 후 상기 용액 $20 \mu l$ 를 HPLC에 주 입하여 분석하였다. HPLC 컬럼은 Zorbax SIL(4.6 x $250 \mathrm{~mm})$ 와, 형광검출기(Ext. $290 \mathrm{~nm}, \mathrm{Em} .330 \mathrm{~nm})$ 를 사 용하여 분석하였다.

\subsection{Phytosterol 분석}

마쇄된 시료 $0.5 \mathrm{~g}$ 을 $3.4 \mathrm{M} \mathrm{NaCl}$ 과 homogenize하고 $4,000 \mathrm{rpm}, 2^{\circ} \mathrm{C}$ 에서 30 분간 원심분리 후, supernatant를 취하여 동일 부피의 $17 \mathrm{mM} \mathrm{NH} \mathrm{H}_{2} \mathrm{PO}_{4} / \mathrm{H}_{3} \mathrm{PO}_{4}(\mathrm{pH}$ $2.87)$ 와 혼합하고, $0.45 \mu \mathrm{m}$ 의 nylon syringe filter를 이 용하여 여과한 후 HPLC(Table 2)로 분석하였다.

Table 2. HPLC conditions

\begin{tabular}{ll}
\hline Equipment & HP Agilent 1200 series HPLC \\
Column & YMC-ODS-AQ, $5 \mu \mathrm{m}, 150 \times 4.6 \mathrm{~mm}$ ID \\
Mobile phase & $17 \mathrm{mM}$ with $300 \mathrm{ppm}$ formaldehyde \\
Flow rate & $0.4 \mathrm{~m} \ell / \mathrm{min}, 0.7 \mathrm{~m} \ell / \mathrm{min}$ \\
Detector & $\mathrm{UV} 215 \mathrm{~nm}$ \\
Oven temperature & $25^{\circ} \mathrm{C}$ \\
\hline
\end{tabular}

2.4. 활성산소 소거능 DPPH (1,1-Diphenyl-2-picrylhydrazyl) 분석

$\mathrm{DPPH}(3.94 \mathrm{mg} / \mathrm{DW} 25 \mathrm{~m} \ell) 400 \mu \mathrm{M}$ 을 완전히 녹인 후, $0.2 \mathrm{M} \mathrm{MES} \mathrm{solution,} 8.53 \mathrm{~g} / 200 \mathrm{~m} \ell(\mathrm{pH}$ 6) 완충용 액, 80 및 $20 \%$ ethanol, $0.2 \mathrm{mM}$ trolox(사용한 동일 용 매에 녹인 다음 $-2{ }^{\circ} \mathrm{C}$ 에서 보관)로 처리하였다. $\mathrm{DPPH}$ 는 그 자체가 매우 안정한 free radical로서 $517 \mathrm{~nm}$ 에서 특징적인 광흡수를 나타내는 보라색 화합물로, 알코 올 등의 유기용매에서 매우 안정하며 proton- radical scavenger에 의하여 탈색되기 때문에 항산화 활성을 육안으로도 쉽게 관찰할 수 있음(Fang 등, 2002; Morrissey 등, 1998; Temple, 2000).

- 전자 공여능 $(\%)$

100 - (시료첨가구 흡광도 / 무첨가구 흡광도) $\times 100$ 으로 계산하여 사용하였다.

\section{3. 결과 및 고찰}

\subsection{Ginsenosides 성분함량의 비교분석}

일반적으로 홍삼생산을 위한 재배는 6년간을 목표 로 하며, 묘삼이 6 년간 생육하면 개체 중량은 100 여배 로, 그리고 수삼 생중량당 ginsenoside(7종) 함량도 2 5년차까지 급격히 증가하여 묘삼의 2 배에 달한다 (박, 1991; 정 등, 1995; 최, 1991; 최광태, 1995). 그러 나 6년차 이후의 ginsenoside 함량은 변화가 적다. 본 조사는 ginsenoside 생성이 활발한 2년생근과 3 년생근 을 대상으로 ginsenoside 성분 함량 동태를 분석하였다 (Tables 3, 4). 수삼의 $100 \mathrm{~g}$ 당 ginsenoside(7종) 함량은 대조구 1,2 와 $\mathrm{KEM}+\mathrm{SAF}$ 처리구의 2 년생근은 각각 $1.16,1.19,1.45 \%$ 이며 3년생근은 각각 $1.97,1.95,2.36 \%$ 로 2년생근에 비하여 $69.5,64.0,62.0 \%$ ginsenoside 함량이 높은 것으로 나타났다. Ginsenoside 종속별로는 $\mathrm{Rd}$ 가 2 년생근은 $0.07 \%, 3$ 년생근은 $0.17 \%$ 로 가장 적 게 나타냈으며, 가장 많은 것은 $\mathrm{Rb}_{1}$ 과 $\mathrm{Re}$ 로 각각 2 년 생근이 $0.29,0.27 \%$ 이고 3 년생근은 $0.42,0.43 \%$ 로 나 타났다. $\mathrm{Rb}_{1}$ 은 중추신경억제 및 정신안정, 진통, 항경 련, 항불안, 기억력 개선에 효과가 있으며, Re는 부신 피질 자극호르몬 분비촉진, 신장사구체 비대 억제에 효과가 있는 것으로 알려져 있다(김 등, 1999; 도와 이, 1993; 박, 1991; 양, 1991; 최, 1991). 
한편 $\mathrm{KEM}+\mathrm{SAF}$ 를 시용한 인삼의 ginsenoside 성분 함량에 미치는 영향에 대하여 분석한 결과, 2 년생근의 경우 대조구에 비하여 $\mathrm{KEM}+\mathrm{SAF}$ 처리구의 ginsenoside 성분 함량이 $24 \%$ 증가한 것으로 나타났으며, 3 년생근 에서도 $20 \%$ 가 증가한 것으로 나타났다. Ginsenoside 성분 종속별로 대조구와 $\mathrm{KEM}+\mathrm{SAF}$ 처리구를 비교하 여 보면, 2 년생근에서 $\operatorname{Re}$ 와 $\operatorname{Rf}$ 는 $14 \%$ 로 비교적 낮은 증가를 보였으나, $\mathrm{Rb}_{2}$ 와 $\mathrm{Rd}$ 에서는 각각 $46 \% \mathrm{KEM}+$ $\mathrm{SAF}$ 처리구가 높게 나타났다(Table 3). 3 년생근에서 는 $\mathrm{Rc}$ 와 $\mathrm{Rb}_{1}$ 에서 각각 $5,15 \%$ 로 비교적 낮은 증가를 보였으며, $\mathrm{Rb}_{2}$ 와 $\mathrm{Rg}_{1}$ 에서는 각각 $30,38 \% \mathrm{KEM}+\mathrm{SAF}$ 처리구가 높은 것으로 나타났다(Table 4). 본 조사 결 과 ginsenoside 성분 함량의 차이는 대조구에 비하여 $\mathrm{KEM}+\mathrm{SAF}$ 처리구에서 $20 \%$ 이상 ginsenoside 함량이 높은 것으로 나타나, 인삼 재배시 $\mathrm{KEM}+\mathrm{SAF}$ 를 주기 적으로 시용하면 ginsenoside 성분 종속별 차이는 있 으나, 전체적으로 ginsenoside 함유량의 증대효과가
기대된다.

\subsection{Vitamin C와 E 성분함량의 비교분석}

Vitamin $\mathrm{C}$ 는 glucose나 galactose 등의 당질 전구 물질로부터 합성되는 일종의 탄수화물이다(식품의약 품안전청, 2012). Vitamin C의 중요한 생화학적 특성 은 vitamin A, D, K, E 등이 지용성인 것과는 달리 수 용성이다. 이러한 특성 때문에 vitamin $\mathrm{C}$ 는 일반적으 로 독성이 없는 것으로 알려져 있다. Vitamin $\mathrm{C}$ 의 기 능은 항산화제로서의 역할이다. 즉 자기 스스로 산화 됨으로 다른 물질의 산화를 막아 주는 역할을 하는 것 으로 알려져 있다(식품의약품안전청, 2012).

인삼의 vitamin $\mathrm{C}$ 성분함량 분석결과, 2 년생 수삼 의 vitamin $\mathrm{C}$ 함량(Fig. 1)은 생물중량 $100 \mathrm{~g}$ 당 대조구 1,2 및 $\mathrm{KEM}+\mathrm{SAF}$ 처리구에서 각각 $24.84,21.74$, $37.13 \mathrm{mg}$ 을 함유하고 있으며, 3년생근(Fig. 2)에서는 각각 $34.31,27.04,42.24 \mathrm{mg}$ 을 함유하고 있는 것으로 나타났다. 또한 2 년생근에 비하여 3 년생근은 각 조사

Table 3. Ginsenosides (main saponine) ingredient content of two-year fresh ginseng

(Unit: \%)

\begin{tabular}{|c|c|c|c|c|c|c|c|c|}
\hline Sample contents & $\mathrm{Rb}_{1}$ & $\mathrm{Rb}_{2}$ & $\mathrm{Rc}$ & $\mathrm{Rd}$ & $\operatorname{Re}$ & $\mathrm{Rf}$ & $\operatorname{Rg}_{1}$ & Total \\
\hline Control I & $\begin{array}{c}0.26 \\
\pm 0.02\end{array}$ & $\begin{array}{c}0.13 \\
\pm 0.02\end{array}$ & $\begin{array}{c}0.15 \\
\pm 0.03\end{array}$ & $\begin{array}{c}0.07 \\
\pm 0.02\end{array}$ & $\begin{array}{c}0.24 \\
\pm 0.02\end{array}$ & $\begin{array}{c}0.12 \\
\pm 0.01\end{array}$ & $\begin{array}{c}0.19 \\
\pm 0.01\end{array}$ & $\begin{array}{c}1.16 \\
\pm 0.06\end{array}$ \\
\hline Control II & $\begin{array}{c}0.28 \\
\pm 0.03\end{array}$ & $\begin{array}{c}0.12 \\
\pm 0.02\end{array}$ & $\begin{array}{c}0.13 \\
\pm 0.02\end{array}$ & $\begin{array}{c}0.06 \\
\pm 0.01\end{array}$ & $\begin{array}{c}0.28 \\
\pm 0.01\end{array}$ & $\begin{array}{c}0.11 \\
\pm 0.01\end{array}$ & $\begin{array}{c}0.22 \\
\pm 0.03\end{array}$ & $\begin{array}{c}1.19 \\
\pm 0.05\end{array}$ \\
\hline Control average & $\begin{array}{c}0.27 \\
\pm 0.02\end{array}$ & $\begin{array}{c}0.13 \\
\pm 0.02\end{array}$ & $\begin{array}{c}0.14 \\
\pm 0.02\end{array}$ & $\begin{array}{c}0.06 \\
\pm 0.01\end{array}$ & $\begin{array}{c}0.26 \\
\pm 0.02\end{array}$ & $\begin{array}{c}0.11 \\
\pm 0.01\end{array}$ & $\begin{array}{c}0.21 \\
\pm 0.02\end{array}$ & $\begin{array}{c}1.17 \\
\pm 0.05\end{array}$ \\
\hline $\mathrm{KEM}+\mathrm{SAF}^{*}$ & $\begin{array}{c}0.32 \\
\pm 0.03\end{array}$ & $\begin{array}{c}0.18 \\
\pm 0.04\end{array}$ & $\begin{array}{c}0.18 \\
\pm 0.02 \\
\end{array}$ & $\begin{array}{c}0.09 \\
\pm 0.04 \\
\end{array}$ & $\begin{array}{c}0.29 \\
\pm 0.02 \\
\end{array}$ & $\begin{array}{c}0.13 \\
\pm 0.02 \\
\end{array}$ & $\begin{array}{c}0.26 \\
\pm 0.03 \\
\end{array}$ & $\begin{array}{c}1.45 \\
\pm 0.05 \\
\end{array}$ \\
\hline $\begin{array}{c}\text { Control/ } \\
\text { KEM+SAF }^{*}(\%)\end{array}$ & 121.3 & 142.9 & 127.7 & 142.1 & 113.5 & 113.4 & 125.8 & 123.9 \\
\hline
\end{tabular}

* KEM: Korean effective microorganisms, SAF: Seafood amino acid fertilizer

Table 4. Ginsenosides (main saponine) ingredient content of three-year fresh ginseng

(Unit: \%)

\begin{tabular}{|c|c|c|c|c|c|c|c|c|}
\hline Sample contents & $\mathrm{Rb}_{1}$ & $\mathrm{Rb}_{2}$ & $\mathrm{Rc}$ & $\mathrm{Rd}$ & $\mathrm{Re}$ & $\mathrm{Rf}$ & $\mathrm{Rg}_{1}$ & Total \\
\hline Control I & $\begin{array}{c}0.40 \\
\pm 0.02\end{array}$ & $\begin{array}{c}0.25 \\
\pm 0.01\end{array}$ & $\begin{array}{c}0.31 \\
\pm 0.02\end{array}$ & $\begin{array}{c}0.18 \\
\pm 0.01\end{array}$ & $\begin{array}{c}0.41 \\
\pm 0.02\end{array}$ & $\begin{array}{c}0.18 \\
\pm 0.01\end{array}$ & $\begin{array}{c}0.24 \\
\pm 0.01\end{array}$ & $\begin{array}{c}1.97 \\
\pm 0.06\end{array}$ \\
\hline Control $\amalg$ & $\begin{array}{c}0.40 \\
\pm 0.02\end{array}$ & $\begin{array}{c}0.28 \\
\pm 0.02\end{array}$ & $\begin{array}{c}0.31 \\
\pm 0.01\end{array}$ & $\begin{array}{c}0.14 \\
\pm 0.00\end{array}$ & $\begin{array}{c}0.41 \\
\pm 0.01\end{array}$ & $\begin{array}{c}0.16 \\
\pm 0.01\end{array}$ & $\begin{array}{c}0.24 \\
\pm 0.01\end{array}$ & $\begin{array}{c}1.95 \\
\pm 0.03\end{array}$ \\
\hline Control average & $\begin{array}{c}0.40 \\
\pm 0.02\end{array}$ & $\begin{array}{c}0.26 \\
\pm 0.02\end{array}$ & $\begin{array}{c}0.31 \\
\pm 0.01\end{array}$ & $\begin{array}{c}0.16 \\
\pm 0.02\end{array}$ & $\begin{array}{c}0.41 \\
\pm 0.02\end{array}$ & $\begin{array}{c}0.17 \\
\pm 0.01\end{array}$ & $\begin{array}{c}0.24 \\
\pm 0.01\end{array}$ & $\begin{array}{c}1.96 \\
\pm 0.04\end{array}$ \\
\hline $\mathrm{KEM}+\mathrm{SAF}^{*}$ & $\begin{array}{c}0.46 \\
\pm 0.02\end{array}$ & $\begin{array}{c}0.34 \\
\pm 0.01\end{array}$ & $\begin{array}{c}0.32 \\
\pm 0.03\end{array}$ & $\begin{array}{c}0.20 \\
\pm 0.01\end{array}$ & $\begin{array}{c}0.48 \\
\pm 0.05\end{array}$ & $\begin{array}{c}0.22 \\
\pm 0.03\end{array}$ & $\begin{array}{c}0.33 \\
\pm 0.02\end{array}$ & $\begin{array}{c}2.36 \\
\pm 0.10\end{array}$ \\
\hline $\begin{array}{c}\text { Control/ } \\
\text { KEM+SAF }(\%)\end{array}$ & 115.4 & 130.4 & 104.9 & 126.3 & 115.8 & 126.9 & 137.5 & 120.4 \\
\hline
\end{tabular}

* KEM: Korean effective microorganisms, SAF: Seafood amino acid fertilizer 
구에서 $38.1,24.4,13.8 \%$ vitamin C 함량이 많은 것으 로 나타났으며, 전체적으로 $23.8 \%$ 3년생근에서 더 많 은 것으로 분석되었다. 한편 관행농업의 대조구와 $\mathrm{KEM}+\mathrm{SAF}$ 처리구 수삼의 vitamin $\mathrm{C}$ 함량(Figs. 1, 2) 은 대조구에 비하여 2년생근에서 $59.4 \%, 3$ 년생근에 서 $37.7 \%$ 높게 나타났으며, 평균 $48.6 \% \mathrm{KEM}+\mathrm{SAF}$ 처리구에서 vitamin $\mathrm{C}$ 함량이 많이 함유돼 있는 것으 로 나타났다(Figs. 1, 2). 상기 결과로 보아 인삼의 vitamin $\mathrm{C}$ 함량은 2년생에서 3년생으로 성장하면서 vitamin $\mathrm{C}$ 함량이 증가되고, $\mathrm{KEM}+\mathrm{SAF}$ 를 시용한 포 장에서 vitamin C 함량이 증가한다는 결과가 얻어졌다.

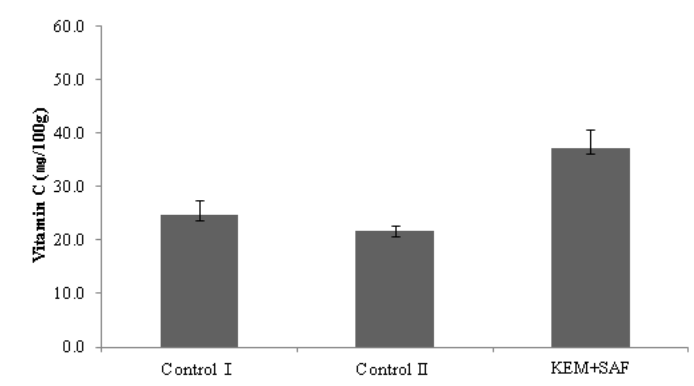

Fig. 1. Vitamin C content comparison of two-year fresh ginseng (mg/100 g, fresh weight).

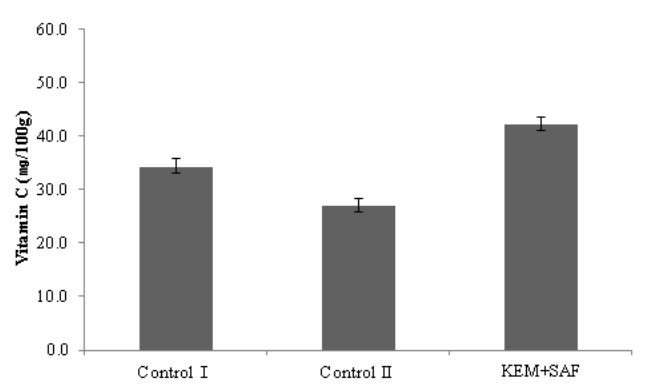

Fig. 2. Vitamin $\mathrm{C}$ content comparison of three-year fresh ginseng (mg/100 g, fresh weight).

Vitamin E는 1936년에 소맥배아유에서 단리 하여, 1938년에 그리스어로 자식, 후손(tocos)이라는 뜻으 로 Tocopherol이라 부르게 되었다(식품의약품안전청, 2012). 다른 지용성 비타민은 간에 저장되는 것과 달 리 vitamin $\mathrm{E}$ 는 지방조직에 저장되며 인체에서 강력 한 항산화작용으로 암을 예방하고 생식기능을 활성 시키며 $a, \beta, \gamma, \delta, \ominus 5$ 종류가 있으며 열과 산에는 안전
하고 알칼리에는 불안하다. 물에 녹지 않으므로 요리 시에 손실은 없으나 산패된 지방이나 철분과 접촉하 면 파괴된다(식품의약품안전청, 2012). 2년생 수삼의 vitamin E 함량(Fig. 3)은 건물중량 $100 \mathrm{~g}$ 당 대조구 1, 2 및 $\mathrm{KEM}+\mathrm{SAF}$ 처리구에서 각각 $53.47,51.27,55.32$ $\mathrm{mg}$ 을 함유하고 있으며, 3년생근(Fig. 4)에서는 각각 $48.28,47.80,48.76 \mathrm{mg}$ 을 함유하고 있는 것으로 나타 났다. 또한 2년생근에 비하여 3 년생근은 각조사구에 서 상대적으로 -9.7, -6.8, -11.9\% vitamin $\mathrm{E}$ 함량이 적 은 것으로 나타났으며, 전체적으로 $-9.5 \% 3$ 년생근에 서 적은 것으로 분석되었다.

한편 관행농업의 대조구와 $\mathrm{KEM}+\mathrm{SAF}$ 처리구 수삼 의 vitamin $\mathrm{E}$ 함량은 대조구에 비하여 $\mathrm{KEM}+\mathrm{SAF}$ 처 리구가 2 년생근에서 $5.6 \%, 3$ 년생근에서 $1.5 \%$ 로 약간 높게 나타났다(Figs. 3, 4). 상기 결과로 보아 인삼의 vitamin $\mathrm{E}$ 함량은 2년생에서 3년생으로 성장하면서 vitamin $\mathrm{E}$ 함량이 약간 감소하는 경향을 보이고, $\mathrm{KEM}+\mathrm{SAF}$ 를 시용한 포장에서 vitamin $\mathrm{E}$ 함량은 약 간 증가한다는 결과가 얻어졌다.

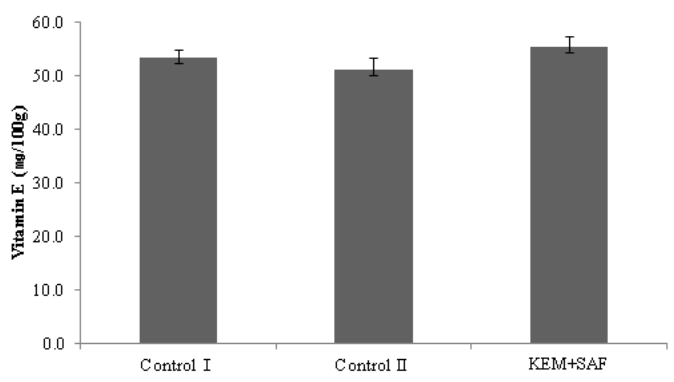

Fig. 3. Vitamin E content comparison of two-year fresh ginseng (mg/100 g, dry weight).

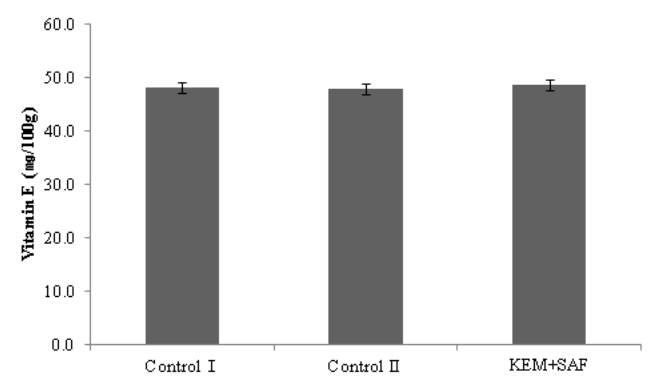

Fig. 4. Vitamin E content comparison of three-year fresh ginseng (mg/100 g, dry weight). 


\subsection{Phytosterol 성분함량의 비교분석}

Phytosterol은 $\beta$-sheetsterol, kanpeseuterol, stigmasterol, brassicasterol 등 40 종류 이상의 sterol 화합물로, 식 품에서는 채소나 과일, 식용유 등에 포함되어 있다. Sterol은 세포막의 안정이나 기능유지를 위해 모든 생 물에게 필요한 지용성의 물질이다(식품의약품안전청, 2012). Phytosterol은 인체소장의 cholesterol 흡수를 억제해 혈액중의 cholesterol 농도를 저하시키는 작용 이 있으며, 전립선 비대에 의한 배뇨 장해의 개선 효과 가 있다. 특히 phytosterol은 total cholesterol, LDL cholesterol 값을 내리는 효과가 있으며, 중성지방, HDL cholesterol 수치에는 영향을 주지 않는다(식품 의약품안전청, 2012). 인삼의 phytosterol에 속하는 3 성분(campesterol, $\mathrm{C}_{28} \mathrm{H}_{48} \mathrm{O}$; stigmasterol; sitosterol) 의 함량 분석결과를 Figs. 5, 6 에 나타냈다. 2 년생근의 campesterol함량은 건물중량 $100 \mathrm{~g}$ 당 대조구 1,2 및 $\mathrm{KEM}+\mathrm{SAF}$ 처리구에서 각각 $0.17,0.24,0.26 \mathrm{mg}$ 을 함 유하고 있으며, 3 년생근에서는 각각 $0.17,0.23,0.25$ $\mathrm{mg}$ 을 함유하고 있는 것으로 나타났다. 또한 2 년생근에 비하여 3 년생근은 각조사구에서 $2.3,-6.0,-3.9 \%$ 로, 2 년생근에 비하여 평균 -3.1 로 적게 나타났다.

한편 stigmasterol은 각각 $3.43,3.35,3.51 \mathrm{mg}$ 을 함 유하고 있으며, 3 년생근에서는 각각 $3.76,3.82,4.05$ $\mathrm{mg}$ 을 함유하고 있는 것으로 나타났다. 또한 2 년생근에 비하여 3 년생근은 각조사구에서 $9.7,13.9,15.3 \%$, campesterol함량은 2년생근에 비하여 높게 나타났다. 그리고 sitosterol은 각각 4.41, 4.39, $5.02 \mathrm{mg}$ 을 함유하 고 있으며, 3년생근에서는 각각 4.64, 4.43, $5.12 \mathrm{mg}$ 을 함유하고 있는 것으로 나타났다. 또한 2년생근에 비하 여 3 년생근은 각조사구에서 $5.2,1.0,2.1 \%$, campesterol 함량은 2 년생근에 비하여 약간 높게 나타났다. 관행농업 의 대조구와 $\mathrm{KEM}+\mathrm{SAF}$ 처리구 수삼의 phytosterol 함량 은 대조구에 비하여 $\mathrm{KEM}+\mathrm{SAF}$ 처리구가 campesterol, stigmasterol, sitosterol 각각 2년생근에서 25.3, 3.6, $14.1 \%, 3$ 년생근에서 $23.6,6.8,12.9 \%$ 높게 나타났으 며, 평균 $14.4 \% \mathrm{KEM}+\mathrm{SAF}$ 처리구에서 많이 함유돼 있는 것으로 나타났다.

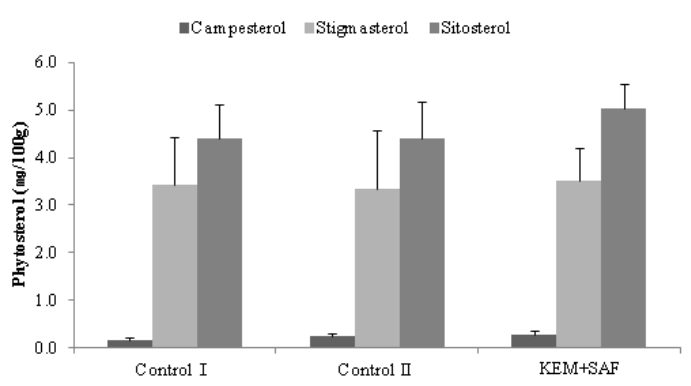

Fig. 5. Content comparison of phytosterol three contents (campesterol; $\mathrm{C}_{28} \mathrm{H}_{48} \mathrm{O}$, stigmasterol, sitosterol) of two-year fresh ginseng (mg/100 g, dry weight).

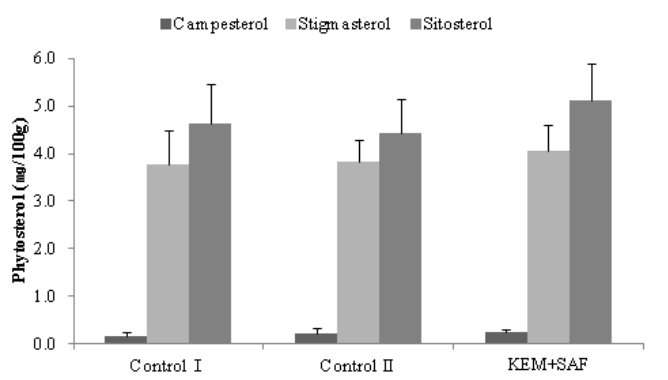

Fig. 6. Content comparison of phytosterol three contents (campesterol; $\mathrm{C}_{28} \mathrm{H}_{48} \mathrm{O}$, stigmasterol, sitosterol) of three-year fresh ginseng $(\mathrm{mg} / 100 \mathrm{~g}$, dry weight).

\section{4. 항산화 물질생성에 미치는 영향}

생물은 공기 중의 산소를 호흡으로 공급받아 유기 물을 산화시켜 생명활동에 필요한 에너지를 얻고 있 지만 그 과정에서 적지만 유해한 활성산소로 불리는 물질이 나올 수 있다. 이 활성산소는 유전자의 본체인 DNA나 세포막을 만들고 있는 지방질 분자를 파괴하 기 위해 여러 가지의 장해를 일으킨다. 그러나 활성산 소라는 것은 사실은 여러 가지의 발암성 물질이나 환 경오염물질 더욱이 방사선이나 자외선 등으로도 발생 한다.

여러 연구에 결과에 의하면 과채류 등과 같은 식물 성 식품을 충분히 섭취하는 것이 노화 지연 및 심혈관 질 환, 동맥 경화, 암, 당뇨 등과 같은 만성질환의 예방과 치 료에 도움이 되는 것으로 밝혀지고 있다(Feskanich 등, 2000; Slavin, 1997; Temple, 2000; Willet, 1994). 활성 산소 소거능(1,1-Diphenyl-2-picrylhydrazyl: DPPH)은 tocopherol, ascorbic acid, polyhydroxy 방향족 화합 
물, 방향족 amine류에 의해 환원되어 짙은 자색이 탈 색되는 정도를 항산화 물질의 전자공여능으로 알려져 있다(Blois, 1958).

인삼의 항산화 물질생성에 미치는 영향을 DPPH (\%)에 의한 전자공여능을 측정한 결과 2 년생 수삼의 $\mathrm{DPPH}$ 는 대조구 1, 2 및 $\mathrm{KEM}+\mathrm{SAF}$ 처리구에서 각각 $12.83,11.96,16.66 \%$ 를 나타냈으며, 3 년생근에서는 각각 $14.24,13.99,20.10 \%$ 를 나타났다(Figs. 7,8$)$. 또 한 2 년생근에 비하여 3 년생근은 각 조사구에서 11.0 , $11.7,20.7 \% \mathrm{DPPH}$ 가 많은 것으로 나타났으며, 전체 적으로 $16.6 \% 3$ 년생근에서 더 높게 분석되었다. 한편 관행농업의 대조구와 $\mathrm{KEM}+\mathrm{SAF}$ 처리구 수삼의 $\mathrm{DPPH}$ 는 대조구에 비하여 $\mathrm{KEM}+\mathrm{SAF}$ 처리구가 2년생 근에서 $34.4 \%, 3$ 년생근에서 $42.4 \%$ 높게 나타났다. 상 기 결과로 보아 인삼의 $\mathrm{DPPH}$ 는 2 년생에서 3 년생으 로 성장하면서 증가되고, $\mathrm{KEM}+\mathrm{SAF}$ 를 시용한 포장 에서 $\mathrm{DPPH}$ 가 증가한다는 결과가 얻어졌다.

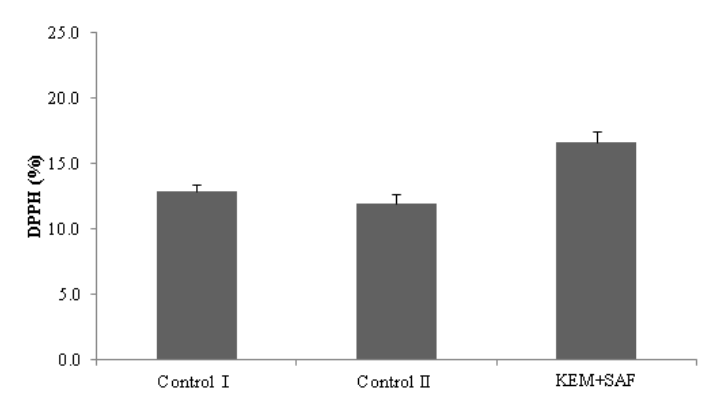

Fig. 7. Comparison of active oxygen-elimination ability (1,1Diphenyl-2-picrylhydrazyl) of two-year fresh ginseng (DPPH; \%, measured wavelength; $517 \mathrm{~nm}$ ).

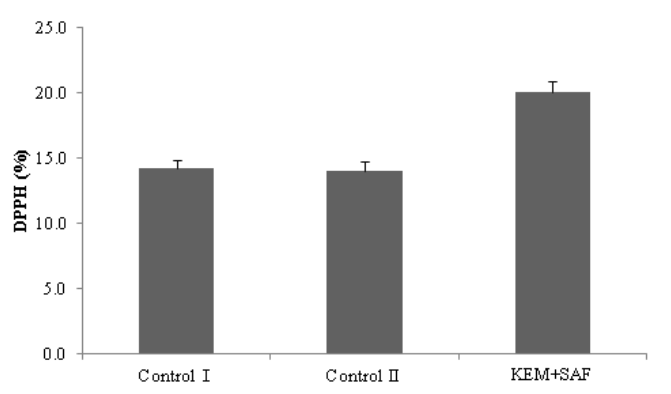

Fig. 8. Comparison of active oxygen-elimination ability (1,1Diphenyl-2-picrylhydrazyl) of three-year fresh ginseng (DPPH; \%, measured wavelength; $517 \mathrm{~nm}$ ).

\section{4. 결 론}

인삼의 saponin 배당체인 30 여종의 ginsenoside와 panacene, methoxypyrazin 등 향의 전구물질인 휘발 성 성분, stearic acid, palmitic acid 등의 지방산, panaxynol, panaxytriol 등의 polyacetylene 화합물, maltol, salicylic acid 등의 페놀화합물, panaxan A E 등의 glucan 다당체, ariginine, glutamic acid 등의 아 미노산, vitamin $\mathrm{B}_{12}$, folic acid 등의 비타민, $a$ -pyrrolidine, $\beta$-carboline 등의 알칼로이드, gomisin $\mathrm{A}$, gomisin $\mathrm{N}$ 등의 리그닌 화합물, kaempherol, panasenoside 등의 플라보노이드, citric acid, malic acid 등의 유기산 및 $\mathrm{Mn}, \mathrm{Ge}$ 등의 미네랄 등, 이외에 도 많은 무기·유기의 성분들이 확인되고 있다(이와 도, 2005; 정 등, 1995; 정 등, 2005; 최, 1991). 이와 같이 인삼에 함유된 다양한 성분 분포는 다른 생약에서는 그 예를 찾아보기 힘들다.

고려인삼(수삼) 2 년생근의 ginsenoside 7 종속의 함 량은 $1.27 \%$ 이며 3 년생근은 $2.09 \%$ 로 2년생근에 비하 여 3년생근은 $64.9 \%$ 증가하였다. 대조구에 비하여 $\mathrm{KEM}+\mathrm{SAF}$ 처리구의 ginsenoside 성분함량은, 2 년생 근의 경우 $24 \%$ 증가하였으며, 3 년생근에서도 $20 \%$ 가 증가하였다. Vitamin C 함량은 대조구에 비하여 2년 생근에서 $59.4 \%, 3$ 년생근에서 $37.7 \% \mathrm{KEM}+\mathrm{SAF}$ 처 리구에서 vitamin C 함량이 높았다. Vitamin $\mathrm{E}$ 함량은 대조구에 비하여 2년생근에서 $5.6 \%, 3$ 년생근에서 $1.5 \% \mathrm{KEM}+\mathrm{SAF}$ 처리구에서 높았으나, 유의한 차는 없었다. Phytosterol 3종류(campesterol, stigmasterol, sitosterol)는 2년생근에서 $25.3,3.6,14.1 \%, 3$ 년생근 에서 $23.6,6.8,12.9 \% \mathrm{KEM}+\mathrm{SAF}$ 처리구에서 높게 나 타났으며, 평균적으로 $14.4 \%$ 많았다. DPPH는 대조 구에 비하여 2년생근에서 $34.4 \%, 3$ 년생근에서 $42.4 \%$ $\mathrm{KEM}+\mathrm{SAF}$ 처리구에서 높았다. 본 결과로 보아, $\mathrm{KEM}+\mathrm{SAF}$ 를 시용한 처리구는 대조구에 비하여 평균 적으로 ginsenoside $22 \%$, vitamin C $48.6 \%$, vitamin E $3.6 \%$, phytosterol $14.4 \%$, DPPH는 $38.4 \%$ 높게 나타 났다. 


\section{참 고 문 헌}

김경제, 김석균, 1999 , 미생물 유기질비료의 시용이 상추 의 수량에 미치는 영향, 한국유기농업학회지, 8(1). 131-138.

김낙두, 2008 , 진세노사이드의 혈관확장작용과 분자기 전, 고려인삼학회지, 32(2), 89-98.

김성훈, 김동희, 이태영, 1999 , 인삼의 본초 및 약리 효능 과 향후 연구방향, 고려인삼학회지, 23(1), 21-37.

김홍기, 서범석, 정순주, 1997 , 미생물부숙퇴비의 상토혼 합처리가 토마토, 고추유묘의 생장에 미치는 영향, 한국유기농업학회지, 5(2), 129-140.

나광출, 조자용, 정순주, 1997 , 광합성세균 배양액의 상 토내 혼입처리가 토마토 플러그묘의 유묘생장에 미 치는 영향, 한국유기농업학회지, 5(2), 105-116.

도재호, 이형옥, 1993 , 인삼 산성다당체의 삼류간 및 부 위별 함량비교, 고려인삼학회지, 17(2), 139-144.

박훈, 1991, 원료삼 품질과 제품의 품질관리, 고려인삼학 회지, 15(3), 224-230.

식품의약품안전청, 2012, http://hfoodi.kfda.go.kr.

안승원, 김계웅, 2010, 친환경농업과 유용미생물활용, 농 상문화사, 1-46.

양덕조, 김용해, 양덕춘, 홍영남, 1994 , 인삼잎의 광합성 과 탄수화물 사포닌 함량에 미치는 항산화제의 효 과, 고려인삼학회지, 18(3), 175-181.

양재원, 1991 , 인삼제품과 기능성 식품 소재의 이용, 고 려인삼학회지, 15(3), 240-246.

이종원, 도재호, 2005 , 건강기능식품의 시장현황 및 인삼 시장의 전망, 고려인삼학회지, 29(4), 192-205.

정열영, 정찬문, 최광태, 1995 , 고려인삼의 연차간 형질 상관 및 경로계수 분석, 19(2), 165-170.

정헌배, 고성권, 박성훈, 조순현, 임병옥, 2005 , 주요 국가 들의 인삼 소비 실태와 인식에 관한 조사, 고려인삼 학회지, 29(3), 145-151.
최강주, 1991 , 원료인삼의 성분과 품질 관리, 고려인삼학 회지, 15(3), 247-256.

比嘉照夫, 1991, 微生物の農業利用と環境保全, 一醱酵合 成型土壤と作物生産-, EMRO, 1-56.

堀井博, 2000 , 大規模経営における畜産堆肥（牛糞）の 有効活用, E M活用技術事例集, 74-81.

Blois, M. S., 1958, Antioxidant determination by the use of a stable free radical, Nature, 26, 1199-1204.

Cho, Y. S., Park, S. G., Jun, S. S., Moon, J. S., Ha, B. S., 1993, Proximate sugar and amino acid composition of Dolsan leaf mustard, J. Korean soc. Food Nutr., 22, 48-52.

Fang, Y. Z., Yang, S., Wu, G., 2002, Free radical, antioxidant and nutrition, Nutrition, 18, 872-879.

Feskanich, D., Ziegler, R. G., Michaud, D. S., Giovannucci, E. L., Speizer, F. E., Willett, W. C., Colditz, G. A., 2000, Prospective study of fruit and vegetable consumption and risk of lung cancer among men and women, J. Natl. Cancer Inst., 92, 1812-1823.

Morrissey, P. A., O`Brien, N. M., 1998, Dietary antioxidant in health and disease, Int Dairy Journal, 8, 463-472.

Park, S. G., Cho, Y. S., Park, J. R., Jun, S. S., Moon, J. S., 1993, Non-volatile organic acids, mineral, fatty acids and fiber compositions in Dolsan leaf mustard (Brassica juncea), J. Korean soc. Food Nutr., 22, 53-57.

Slavin, J. L., Jacobs, D., Marquart, L., 1997, Whole-grain consumption and chronic disease, protective mechanism, Nutr Cancer, 27, 14-21.

Temple, N. J., 2000, Antioxidants and disease: more question than answers, Nurt Res, 20, 449-459.

Willet, W. C., 1994, Diet and health: what should we eat, Science, 254, 532-537. 